Universidade de Brasília

Centro de Excelência em Turismo

\title{
IMPORTÂNCIA DA EDUCAÇÃO NA ATIVIDADE TURÍSTICA
}

\author{
Leone Carneiro Santos
}

Orientadora: Ana Maria de Moraes Sarmento Vellasco

Monografia apresentada ao Centro de Excelência em Turismo da Universidade de Brasília como requisito parcial para a obtenção do certificado de Especialista em Pesquisa e Docência em Turismo e Hospitalidade

Brasília, DF, 2003. 


\author{
UNIVERSIDADE DE BRASÍLIA \\ Centro de Excelência em Turismo \\ Curso de Especialização em Turismo e Hospitalidade
}

\title{
IMPORTÂNCIA DA EDUCAÇÃO NA ATIVIDADE TURÍSTICA
}

Leone Carneiro Santos

Banca Examinadora

Ana Maria de Moraes Sarmento Vellasco, Mestre

Brasília, DF, 2003. 


\section{LEONE CARNEIRO SANTOS}

Comissão Avaliadora

Orientadora: Ana Maria de Moraes Sarmento Vellasco

Prof. Domingos Spezzia

Prof. 
Dedico essa monografia a todas as pessoas que, no futuro, consultarão esse trabalho.

Que esta pesquisa possa ajudá-las na sua vida profissional e pessoal. 
Agradeço a Deus, aos meus pais, Lucídio e Judithlita, aos meus irmãos, Lara, Lucídio Júnior, Lea e Lucas, ao meu esposo Bosco, à minha professora orientadora Ana Maria, ao meu aluno André que me ajudou na realização desta pesquisa e a todos que colaboraram, de alguma maneira, na elaboração desta monografia. 
"Em nenhum outro país do mundo a sensualidade, a oralidade, a alegria e a inclusividade conseguem conviver numa síntese tão incandescente. Um povo mestiço, cordial, civilizado, pobre e sensível habita esta paisagem de sonho, diria Jorge Amado.

É este o lugar: é no Brasil, neste país tão puro e tão contaminado, que eu gostaria de alimentar o meu ócio criativo". (Domenico de Masi) 
RESUMO: identificar o que as pessoas pensam sobre o turismo, pois, acreditase que muitos têm uma idéia pejorativa da área e do profissional que atua nela, além de associarem o turismo apenas ao ato de viajar. Tece-se, também, um estudo sobre os cursos de nível superior de turismo em funcionamento no Brasil, pois, acredita-se que há uma forte relação entre a educação e a visão que muitos têm sobre a profissão e o profissional da área. São os profissionais da área que têm o papel de mudar essa situação. E para isso, eles devem ser qualificados e se fazerem reconhecidos no mercado de trabalho.

PALAVRAS-CHAVES: Turismo, Educação e Visão Profissional. 
ABSTRACT: These research intents to identify people's thought about tourism, because it's believed that many of them have a bad idea about this area and its professional. Moreover they associate it to travelling only. A study about tourism school courses in Brazil is also done, seeing that there's a strong connection between education and the opinion that people have about the tourism profession and its professionals. The tourism professionals just can change this situation. And for that, they should be well prepared and they have been recognized in the job market.

Key Words: Tourism, Education and Professional Vision. 
Lista de Tabelas .................................................................................. vii

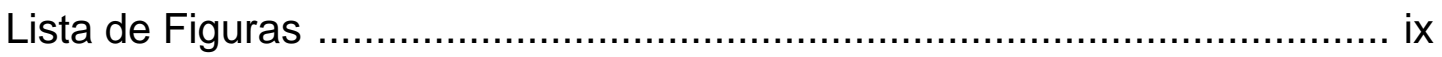

Lista de Abreviaturas............................................................ $\mathrm{x}$

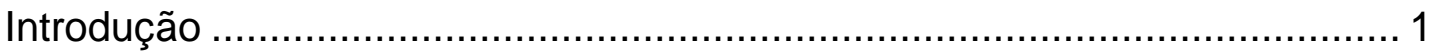

1. Turismo: Conceitos e Definições ............................................................ 4

2. A Profissão e O Profissional ....................................................... 6

2.1 Um Pouco de História............................................................ 6

2.2 Importância da Educação para o Turismo ...................................... 9

2.3 Cursos Superiores de Turismo .............................................. 15

3. Descrição da Metodologia de Pesquisa ................................................ 25

3.1 Ciência e Metodologia Científica ………………………….... 25

3.2 Início e Evolução da Pesquisa Turística.................................... 26

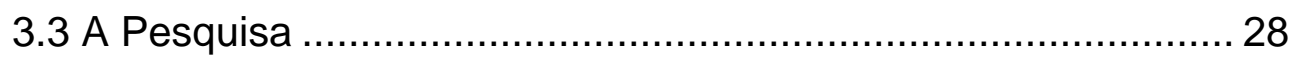

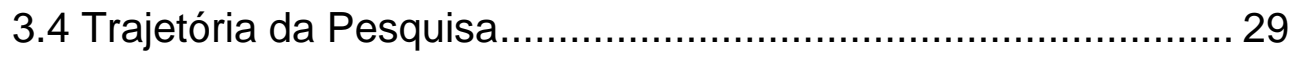

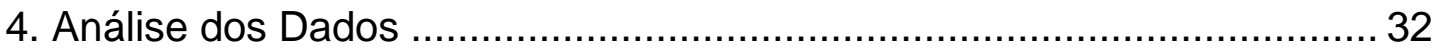

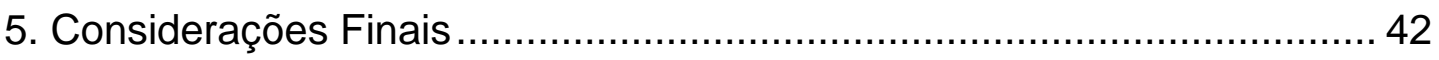

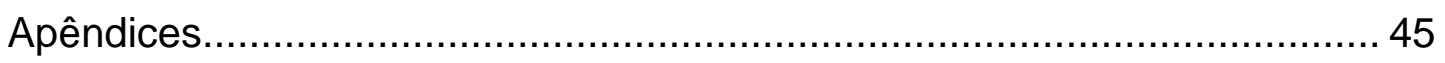


Referência Bibliográfica 


\section{LISTA DE TABELAS}

Tabela 1 - Cursos de Graduação em Turismo no Brasil 1996 pág. 16

Tabela 2 - Cursos de Graduação em Turismo e Áreas Afins na Região Nordeste 2003 pág. 17

Tabela 3 - Cursos de Graduação em Turismo e Áreas Afins na região Norte 2003 pág. 17

Tabela 4 - Cursos de Graduação em Turismo e Áreas Afins na Região Sul 2003 pág. 18

Tabela 5 - Cursos de Graduação em Turismo e Áreas Afins na Região Sul 2003 pág. 18

Tabela 6 - Cursos de Graduação em Turismo e Áreas Afins na região CentroOeste 2003 pág. 18

Tabela 7 - Competências Formais do Professor segundo Demo pág. 23

Tabela 8 - O Que é Turismo? - Questão 2 / Tipo A pág. 33

Tabela 9 - O Que faz o Profissional de Turismo - Questão 3 / Tipo A pág. 35

Tabela 10 - Motivos para Estudar Turismo - Questão 4 / Tipo B pág. 37

Tabela 11 - Visão Sobre Turismo Antes e Depois de Entrar na Faculdade Questão 5 / Tipo B pág. 40 


\section{LISTA DE FIGURAS}

Figura 1 - Quantidade de Cursos de Turismo nos Anos de 1996 e 2003 pág. 6

Figura 2 - Pesquisa da Revista Turismo pág. 13

Figura 3 - Cursos de Turismo e Áreas Afins por Região em Porcentagem no Ano de 1996 pág. 15

Figura 4 - Cursos de Turismo e Áreas Afins por Região em Quantidade no Ano de 2003 pág. 19

Figura 5 - Cursos de Turismo e Áreas Afins por Região em Porcentagem no Ano de 2003 pág. 19

Figura 6 -Distribuição por Sexo Questão 1 / Tipo A pág. 32

Figura 7 -Distribuição por Sexo Questão 1 / Tipo B pág. 35

Figura 8 -Distribuição por Faixa Etária Questão 2 / Tipo B pág. 36

Figura 9 -Distribuição por Sexo Questão 3 / Tipo B pág. 36 


\section{LISTA DE ABREVIATURAS}

ABBTUR Associação Brasileira de Bacharéis em Turismo

FACEB Faculdade Cenecista de Brasília

IES Instituição de Ensino Superior

IUA International Associations Universities

LDB Lei de Diretrizes e Bases da Educação Nacional

$\mathrm{OAB}$ Ordem dos Advogados do Brasil

OMT .Organização Mundial do Turismo

PNT Plano Nacional de Turismo

UNIP Universidade Paulista UPIS União Pioneira de Integração 


\section{INTRODUÇÃO}

- "Meu filho, você quer mesmo fazer turismo?".

- "Turismo? Nem pense nisso!" (De Lucca, 2003).

As frases acima foram extraídas do texto de Vinícius De Lucca Filho cujo título é Entrei no Curso de Turismo. E agora? (De Lucca, 2003). São frases que refletem a maneira como muitas pessoas pensam sobre o que seja turismo.

Além disso, são interrogações feitas às pessoas que decidem estudar turismo na faculdade sendo comum ouvir comentários de cunho pejorativo sobre o turismo e a profissão, como por exemplo, quem estuda turismo acha que vai passar o resto da vida viajando, quem estuda turismo na faculdade está "fazendo" turismo ou ainda exemplo como o do texto de Lucca Filho, citado acima.

Acredita-se que tal situação já se vem modificando um pouco. No entanto, ainda percebe-se que tal opinião ainda é compartilhada por muitas pessoas. Por isso, decidiu-se analisar, por meio de uma pesquisa, o que as pessoas pensam sobre a profissão e o profissional de turismo, baseando-se nas seguintes hipóteses:

- A falta de conhecimento sobre o que é turismo e sua importância é um dos elementos que colabora para a formação da opinião pejorativa que muitos têm do profissional e da profissão de turismo;

- Turismo é associado apenas a viagens por grande parte das pessoas. Acredita-se que isso ocorra pela falta de conhecimento que elas têm sobre o assunto;

- Uma educação de qualidade oferecida tanto pelos cursos de nível superior quanto técnico pode colaborar para que se deixe de ter um pensamento pejorativo sobre o turismo e o profissional da área; 
Os objetivos deste trabalho são:

- $\quad$ Identificar o que as pessoas pensam sobre o turismo;

- Analisar que elementos podem contribuir para fortalecer uma imagem positiva sobre a profissão e o profissional de turismo;

- Verificar quais as opiniões negativas e positivas sobre a profissão e o profissional de turismo.

Levando-se em consideração as hipóteses e os objetivos citados acima, esta pesquisa foi elaborada com a intenção de analisar, num primeiro instante, a opinião que as pessoas têm sobre a profissão e o profissional de turismo, pois, acredita-se que muitos pensam que turismo é só viajar e quem estuda turismo na faculdade está fazendo "turismo".

Num segundo instante, far-se-á um estudo sobre a educação superior na atividade turística. Isso porque se acredita que há uma forte relação entre a educação e a visão que muitos têm sobre a profissão e o profissional da área. São os profissionais da área que têm o papel de mudar essa situação. E para isso, eles devem ser qualificados e se fazerem reconhecidos no mercado de trabalho.

Para se alcançar os objetivos e comprovar ou refutar as hipóteses, optouse por realizar uma pesquisa com estudantes de turismo e diversas pessoas que não tinham contato com a atividade turística.

Esta monografia é divida em seis capítulos. No primeiro capítulo, definese o que é turismo. No segundo capítulo, tece-se um panorama sobre a evolução da educação em turismo no mundo e no Brasil e sua importância para a atividade. No terceiro capítulo é abordada a metodologia de pesquisa bem como sua trajetória. No quarto capítulo analisam-se os dados obtidos com a pesquisa. Por último, tecem-se as considerações finais. 


\section{TURISMO: CONCEITOS E DEFINIÇÕES}

Conceituar turismo não é uma tarefa fácil (fazê-lo é mais fácil), pois, são inúmeras as definições, como também, os autores que tratam do assunto.

Como afirma a Organização Mundial do Turismo (OMT, 2001:35), existe um amplo debate sobre o que seja exatamente turismo. Deve-se considerar que não existe definição correta ou incorreta, já que todas contribuem, de alguma maneira, para a atividade turística. Assim, pode-se definir turismo tendo como referência aspectos econômicos, geográficos, jurídicos e sociológicos, entre outros.

Para Barreto (1998: 9), a primeira definição sobre turismo remonta a 19101991. O austríaco Herman von Schullard definiu turismo como sendo a soma das operações, principalmente de natureza econômica, que estão diretamente relacionadas com a entrada, permanência e deslocamento de estrangeiros para dentro e fora de um país, cidade ou região.

Pode-se, também, conceituar turismo tendo como enfoque o direito: o conjunto de relações e fenômenos que se originam do ato ou fato jurídico que leva a efeito o indivíduo para empreender ou realizar uma viagem e obter sua morada legal em lugar distinto da sua habitual. No que tange à psicologia, o turismo sugere uma saída, algo diferente, estranho, fora do comum: uma experiência de vida do viajante. A quebra da rotina pode funcionar como um estímulo para a volta da rotina ou, como liberador de inibições inculcadas pelo cotidiano.

Para a OMT (2001: 38), turismo é a atividade realizada por pessoas durante suas viagens e estadas em lugares diferentes ao seu entorno habitual, por um período inferior a um ano, com finalidade de lazer, negócios ou outros. 
Outra definição interessante é aquela que aborda o aspecto holístico da atividade turística. Como afirma Beni (1998: 38), essas definições procuram abranger a essência total do assunto. Jafar Jafari (citado em Beni, 1998: 38) defini turismo sob o enfoque holístico como sendo o estudo do homem longe do seu local de residência, da indústria que satisfaz suas necessidades, e dos impactos que ambos, ele e a indústria, geram sobre os ambientes físico, econômico e sociocultural da área receptora.

Para Oscar de La Torre Padilla "turismo é um fenômeno social que consiste em deslocamento voluntário e temporal de indivíduos ou grupos de pessoas que por motivo de recreação, descanso, cultura ou saúde, vão de seu lugar de residência habitual a outro, sem que exerçam atividade lucrativa e remunerada gerando múltiplas inter-relações de importância social, econômica e cultural".

Dos conceitos expostos acima e de muitos outros acerca sobre o que seja turismo, é pertinente analisar os seguintes aspectos: a questão do tempo de permanência no núcleo receptor e a variável remuneração na atividade turística.

Muitas definições ainda consideram turistas só as pessoas que permanecem mais de 24 horas na localidade visitada e que não exerçam atividade remunerada durante a viagem. De comum acordo com Lage e Milone (2000: 26), esses conceitos já são considerados ultrapassados. Comungando com esses autores, Oliveira (2002: 39) afirma: "existe uma nova concepção de turismo que dispensa essas limitações para considerar uma viagem como de turismo".

Verifica-se, em alguns destinos turísticos, a presença de pessoas que fazem turismo e, ao mesmo tempo, exercem alguma atividade remunerada, geralmente, empregos temporários, para custear a própria estada no local visitado.

\footnotetext{
${ }^{1}$ Apostila do Centro de Excelência em Turismo da Universidade de Brasília, setembro, 2003.
} 
Acredita-se, que nem por isso, deixam de ser turistas já que consomem em algum momento, produtos do turismo (restaurantes, hotéis, transportes).

Assim, acredita-se que existam aspectos mais relevantes a serem considerados pelos profissionais do turismo, como por exemplo, os efeitos econômicos, sociais, culturais e ambientais da atividade, os efeitos de saturação do turismo nos núcleos receptores, os impactos positivos e negativos da atividade, entre outros.

O conceito de Mathieson e Wall (citado em Oliveira, 2002: 39) vem a confirmar o defendido anteriormente:

"Turismo é o movimento temporário de pessoas para locais de destinos distintos de seus lugares de trabalho e de morada, incluindo também as atividades exercidas durante a permanência desses viajantes nos locais de destino e as facilidades para promover suas necessidades".

Depois de apresentar diversos conceitos sobre turismo, é importante enfatizar que o mesmo deve-se estudá-lo como um todo e não apenas em partes, para que se chegue a um conceito aceito por todos e para que não ocorram choques culturais, naturais, políticos, sociais e econômicos nos centros receptores. Ou melhor, não se pode estudar e limitar o turismo a uma única definição, pois, como afirma Ansarah (2001: 16), "o turismo encontra-se ligado a quase todos os setores da atividade social". 


\section{A PROFISSÃO E O PROFISSIONAL}

\subsection{Um Pouco de História}

O turismo no Brasil tem o seu desenvolvimento a partir da década de 70. Foi também nessa década que surgiu o primeiro curso superior em turismo no ano de 1971 na Faculdade do Morumbi em São Paulo conhecida, atualmente, como Universidade Anhembi-Morumbi (Trigo, 2001: 243).

Desde então se verifica que o número de cursos aumentou consideravelmente nós últimos anos, como mostra a Figura 1.

Figura 1 - Quantidade de cursos de turismo nos anos de 1996 e 2003.

\section{Cursos de Turismo no Brasil}

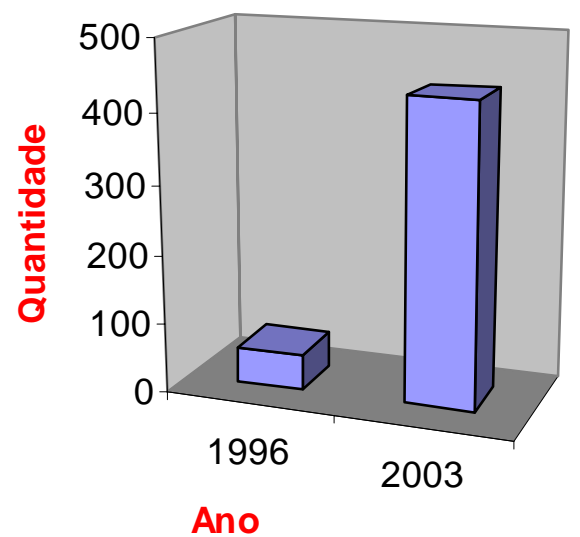

Considera-se a educação fundamental para a atividade turística, pois como afirma Rejowski (2001: 13), "o processo de desenvolvimento do turismo está estreitamente ligado à pesquisa e ao ensino. Ainda segundo Rejowski (2001: 13)", assim ocorre, também, na área do turismo. A pesquisa e o ensino impulsionam e provocam o processo de maturação da área...". Por isso, conhecer suas origens é de suma importância para o entendimento da sua posição no mercado e na 
sociedade. No entanto, mais importante ainda, é que ela seja de qualidade para que não comprometa a imagem dos profissionais da área.

Pode-se afirmar que a educação do turismo, no Brasil, como também, em âmbito internacional, é bastante recente.

No livro Educando os Educadores em Turismo, editado pela Organização Mundial do Turismo (OMT, 2001: 27), tem-se um panorama sobre as origens da educação em turismo. Segundo os autores, uma das origens seriam os cursos oferecidos aos chefs e garçons. Outra possibilidade é que a educação em turismo teria surgido na década de 50, quando houve grande treinamento para os agentes de viagem. Uma terceira possibilidade é que a educação em turismo tenha-se desenvolvido na década de 60 junto com os cursos de hotelaria. Por último, acredita-se que foi por intermédio de outras disciplinas que o turismo se desenvolveu enquanto área de estudo.

Para Cooper, Shepherd e Westlake (citados em Teixeira, 2003), existem três maneiras pelas quais o estudo do turismo se desenvolveu como disciplina acadêmica, a saber: inicialmente, treinamentos específicos para o setor de viagem. Depois, cursos na área de negócio e, posteriormente, com inserção em disciplinas tradicionais como geografia, sociologia e lingüística.

Beni (1992: 9) descreve sobre o desenvolvimento da educação em turismo em alguns países, como por exemplo, Alemanha, Espanha, Venezuela, Países Baixos, entre outros.

Um dos aspectos mais relevantes foi que a formação superior em turismo tornou-se objeto de discussão apenas em 1964, precisamente, na Espanha, indo ao encontro da afirmação feita anteriormente que a educação do turismo é bastante recente. A partir de então, diversos países passaram a se preocupar com o tema, havendo diferentes enfoques que variam de país a país. 
$\mathrm{Na}$ França, por exemplo, os cursos superiores de turismo preparam para profissões de hotelaria e de restauração, sendo o último, quase não difundido no Brasil.

Nos Estados Unidos, ainda segundo Beni, o país não possui um posicionamento apropriado dos programas educacionais em turismo.

Na América do Sul, a Argentina destaca-se perante os outros países latinoamericanos. Lá, as diversas Universidades e Institutos Superiores formam bacharéis em turismo, técnicos em turismo e recreação, guias de turismo, bacharéis em administração de empresas com orientação em turismo, dentre outros. $^{2}$

Foi num Brasil mergulhado na ditadura militar que a educação em turismo foi implantada (início da década de 70).

Por ser uma atividade nova, causava um certo desconforto em muitos. Falar em curso universitário que ensinasse turismo era heresia, pois, acreditavase que para aprender turismo, a maneira ideal era o trabalho diário, prático.

Como afirma Trigo (2000: 243), "a verdade era que pouca gente conhecia essa nova área".

Mesmo com alguns problemas e entraves, a educação em turismo foi implantada. Ainda consoante com Trigo (2000: 245), um curso promissor num país promissor.

\footnotetext{
${ }^{2}$ Dados de 1992.
} 


\subsection{Importância da Educação para o Turismo}

Como já defendido anteriormente, conhecer as origens da educação em turismo é de suma importância para a atividade. E mais, que essa educação seja de qualidade.

Andrade (1998: 38), sugere que a pessoa humana é o epicentro da atividade turística, ou seja, são as pessoas as autoras dessa atividade. Essa importância dada ao homem enquanto turista pode ser, também, transferida ao homem enquanto profissional do turismo, ou seja, as pessoas que trabalham, de alguma maneira, na atividade designada turística.

Tão importante quanto o turista (consumidor do turismo) é o profissional de turismo, pois, o mesmo é responsável pelo bemestar da pessoa que pratica turismo em seu tempo livre. Desse modo, é importante uma educação qualificada do profissional tomando por base a educação como balizador para tal atividade.

Segundo Oliveira (2002: 71), os princípios básicos do turismo são: cama, caminho, compras, comida e carinho. Ele também afirma que o princípio do carinho, talvez seja o mais importante de toda atividade, pois, como já citado acima, é o profissional que colabora e é responsável pela satisfação do turista. E para que o turismo seja desenvolvido e praticado da melhor maneira, é necessário que os atuantes da área sejam pessoas preparadas para tal.

Conforme Ansarah (citado em Silvia, 1995: 45), para o desenvolvimento no sentido de se caracterizar uma oferta de qualidade, faz-se necessária uma formação profissional também de qualidade.

Para Beni (1992: 8), devido ao rápido desenvolvimento tecnológico, turistas mais exigentes e condições conjunturais cada vez mais em transformação, é necessário aperfeiçoamento e treinamento inicial e permanente para proporcionar sólida formação aos profissionais do turismo, como também, proporcionar um melhor atendimento ao turista. 
Acredita-se que cursos formadores de bacharéis e profissionais de turismo têm suma importância para mudar a realidade do turismo brasileiro. Por isso, dáse tanto valor ao profissional da área. Porque se acredita que são estes profissionais os responsáveis pelo desenvolvimento sustentável da atividade.

Em diagnóstico elaborado pelo governo federal sobre o turismo brasileiro e apresentado no recém lançado Plano Nacional de Turismo (2003-2007), PNT, nota-se que apesar do turismo ter se desenvolvido muito nos últimos anos, há problemas que ainda impedem um desenvolvimento mais expressivo. Um dos problemas é, justamente, a qualificação profissional deficiente dos recursos humanos do setor, tanto no âmbito gerencial quanto nas habilidades operacionais.

Como proposta para reverter esse quadro, um dos Macros Programas do PNT (2003-2007), é o da QUALIDADE DO PRODUTO TURÍSTICO. Um dos seus objetivos é promover a capacitação, qualificação e a re-qualificação dos agentes atuantes em toda a cadeia produtiva do turismo, nos diversos níveis hierárquicos, tanto do setor público quanto privado visando ocupar os novos postos de trabalho gerados.

No PNT (2003-2007) também consta que as instituições educativas merecem uma atenção particular porque sobre elas recai o enorme compromisso de formar profissionais em todos os níveis para o setor.

Como um dos objetivos desse trabalho é analisar a importância da educação para o setor turístico, espera-se que essa preocupação e interesse do governo pela qualificação dos profissionais da área realmente possam colaborar para que isso realmente aconteça.

De acordo com a Lei de Diretrizes e Bases da educação Nacional - LDB, as finalidades do ensino superior são:

Art. 43. A educação superior tem por finalidade: 
I. Estimular a criação cultural e o desenvolvimento do espírito científico e do pensamento reflexivo;

II. Formar diplomados nas diferentes áreas de conhecimento, aptos para a inserção em setores profissionais e para a participação no desenvolvimento da sociedade brasileira, e colaborar na sua formação contínua;

III. Incentivar o trabalho de pesquisa e investigação científica, visando ao desenvolvimento da ciência e da tecnologia e da criação e difusão da cultura e, desse modo, desenvolver o entendimento do homem e do meio em que vive;

IV. Promover a divulgação de conhecimentos culturais, científicos e técnicos que constituem patrimônio da humanidade e comunicar o saber através do ensino, de publicações ou de outras formas de comunicação;

V. Suscitar o desejo permanente de aperfeiçoamento cultural e profissional e possibilitar a correspondente concretização, integrando os conhecimento que vão sendo adquiridos numa estrutura intelectual sistematizadora do conhecimento de cada geração;

VI. Estimular o conhecimento dos problemas do mundo presente, em particular os nacionais e regionais, prestar serviços especializados à comunidade e estabelecer com esta uma relação de reciprocidade;

VII. Promover a extensão, aberta à participação da população visando à difusão das conquistas e benefícios resultantes da criação cultural e da pesquisa científica e tecnológica geradas na instituição.

Na visão de Ansarah (2001: 14), a educação universitária em turismo deve proporcionar um conjunto de ferramentas direcionadas para a interpretação e a evolução de novos conhecimentos, possibilitando ao bacharelando desenvolver sua capacidade crítica. Ainda consoante Ansarah, as universidades, enquanto instituições voltadas para a educação, têm o compromisso de direcionar os estudos para:

- Estimular e despertar a preocupação com a pesquisa e a investigação;

- Estimular o desenvolvimento da capacidade crítica, avaliativa e criativa;

- $\quad$ Proporcionar um maior embasamento cultural e humanístico; 
- $\quad$ Formar recursos humanos para o mercado de trabalho;

- Preparar os profissionais para novas tecnologias, novos equipamentos e novos materiais.

Percebe-se uma ligação entre as ferramentas elencadas por Ansarah e as finalidades da educação superior citadas no artigo 43 da LDB. Assim, acredita-se que a educação universitária para a atividade turística é fundamental para o setor, pois o turismo no Brasil precisa de profissionais treinados, criativos, qualificados e que gostem do que faz. E mister que esses profissionais se qualifiquem, seja em um curso universitário seja em um curso de nível médio, embora a ênfase desse trabalho recaia sobre as Instituições de Ensino Superior.

Sabe-se que os cursos de turismo de nível superior passaram por uma verdadeira explosão na quantidade e não na qualidade, o que pode colaborar para a manutenção de uma imagem pejorativa dos profissionais e da profissão.

Como afirma Rejowski (2001: 60), o turismo penetra no meio acadêmico pouco conhecido e visto de forma pejorativa. Ou melhor, dizia-se e diz-se: quem estuda turismo em faculdade está fazendo "turismo".

Pode-se dizer que este cenário mudou, o que não significa que ainda não exista preconceito. Ainda hoje, quando alguém fala que ensina ou estuda turismo, a primeira pergunta que se faz é: para onde é melhor viajar?(Tineu, 2002).

Uma pesquisa feita pela Revista Turismo via internet tentou descobrir quais eram os principais fatores para um maior desenvolvimento do turismo no Brasil. Os resultados encontrados constam na Figura 2. ${ }^{3}$

\footnotetext{
${ }^{3}$ Pesquisa realizada em dezembro de 2000 pela Revista Turismo disponível no site www.revistaturismo.com.br
} 
Figura 2 - Pesquisa da Revista Turismo realizada em dez. de 2000.

\section{Qual o principal tator para o maior desenvolvimento do Turismo no Brasil ?}

Inoentivo do governo

Melhor infra-estutura

Inuestimento maior na qualificaçó profisional

Melhoria nas agências de viagens

Maior diưlgagăo, Marketing

Total: 214 votos
$19.16 \%(41$ wotos)

$24.77 \%(53$ uotos

$21.50 \%(46$ votos)

$13.08 \%$ (28 votos)

$21.50 \%(40$ uotos)

Como se pode verificar, a qualificação profissional foi apontada como o segundo fator mais importante para o desenvolvimento do turismo no Brasil.

Por isso, mais uma vez, defende-se que uma educação de qualidade é fundamental para a melhoria da imagem da profissão e do profissional, pois, como afirma Trigo (2003), um dos problemas do turismo brasileiro é de qualidade mesmo!

O turismo é uma atividade em crescimento no Brasil e no mundo. Estimase que ela deva criar novos empregos nos diversos setores da economia devido o aumento da demanda. Mas como afirma Nakamura (2000: 2):

"Mas nem tudo é festa. Apesar da crescente oferta de vagas nos mais diversos cargos de redes hoteleiras, os empregadores reclamam da carência de mão-de-obra qualificada. A escolaridade das pessoas disponíveis para funções operacionais é baixa. Como agravante, há grande carência de profissionais polivalentes no mercado.Durante muito tempo houve um certo menosprezo pela formação profissional. Era o tempo em que se repetia, de forma leviana, que essas coisas não se aprendiam na escola. Passados alguns anos, a hotelaria e o turismo surgem como estrelas nas escolas superiores. Houve uma época em que expressões como sociedade pós-industrial, setor terciário e formação profissional 
para o mercado eram desconhecidas ou menosprezadas, sendo hoje mais valorizadas".

Demo (2000: 46) afirma que educação é o suporte essencial, porque, no lado formal, instrumenta a pessoa com habilidade crucial de manejar a arma mais potente de combate que é o conhecimento.

Percebe-se que, ultimamente, muitos têm se preocupado com uma educação (de qualidade). Em decorrência disso, estão ocorrendo seminários, congressos, palestras sobre o tema. Dá-se em destaque para uma reunião organizada pela International Association of Universities - IAU sobre uma educação sustentável para o futuro (Cortez, 2003: 2).

Uma das discussões nessa reunião foi como uma educação de qualidade pode interferir num futuro sustentável do mundo tanto ao meio ambiente como ao meio social. Como proposta para que isso ocorra, tem-se: treinamento de docentes baseados no conceito de sustentabilidade, importância de uma educação interdisciplinar que é uma característica própria da atividade turística, entre outros.

Sabe-se que muito deve ser feito para que realmente haja uma educação baseada na qualidade. Mas acredita-se que são trabalhos como esse e tantos outros sobre esse tema que podem mudar tal cenário. 


\subsection{Cursos Superiores de Turismo}

Como já citado antes, o primeiro curso superior em turismo surgiu em 1971. Na década de 90, houve uma explosão significativa no número de cursos criados.

A título de exemplo, em 1996, havia 40 cursos de turismo, 8 de hotelaria, 1 de turismo e hotelaria e 3 de outras áreas, Geografia, Administração e Arquitetura, com ênfase em planejamento turístico, hotelaria e turismo, conforme mostra a Tabela 1 (Ansarah e Rejowski, 1996: 38). A maioria dos cursos estava presente na região Sudeste (48\%), seguida da região Nordeste (23\%), em terceiro a região Sul com $17 \%$ dos cursos, a região Norte com $8 \%$ e, por último, a região Centro-Oeste com 4\% (verificar Figura 3).

Figura 3 - Cursos de Turismo e áreas afins por região em porcentagem no ano de 1996.

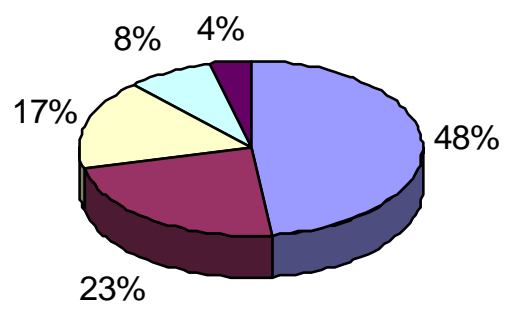

$\square$ Região Sudeste

$\square$ Região Nordeste

$\square$ Região Sul

$\square$ Região Norte

- Centro-Oeste

Dados da Associação Brasileira de Bacharéis em Turismo - ABBTUR em 2003 mostram que há, atualmente, cerca de 430 cursos de turismo e áreas afins (verificar Tabelas 2 a 6). A maioria dos cursos é de graduação em turismo para citar os mais expressivos em quantidade. Percebe-se, assim, que houve um aumento de mais de 800\% em relação ao não de 1996. 
Tabela 1 - Cursos de Graduação em Turismo, Hotelaria e Áreas afins no Brasil por Estado-1996.

\begin{tabular}{|c|c|c|c|c|c|c|}
\hline \multirow{3}{*}{ Estados } & \multicolumn{6}{|c|}{ Cursos de Graduação } \\
\hline & \multirow{2}{*}{ Turismo } & \multirow{2}{*}{ Hotelaria } & \multirow{2}{*}{$\begin{array}{l}\text { Turismo e } \\
\text { Hotelaria }\end{array}$} & \multirow{2}{*}{$\begin{array}{c}\text { Geografia } \\
\text { Planejamento } \\
\text { Turístico }\end{array}$} & \multirow{2}{*}{$\begin{array}{c}\text { Administração } \\
\text { Hoteleira }\end{array}$} & \multirow{2}{*}{$\begin{array}{l}\text { Total } \\
\text { Quant }\end{array}$} \\
\hline & & & & & & \\
\hline Amazonas & 3 & & & & & 3 \\
\hline Pará & 1 & & & & & 1 \\
\hline Maranhão & 1 & 1 & & & & 2 \\
\hline Ceará & 1 & & & & & 1 \\
\hline $\begin{array}{l}\text { Rio Grande } \\
\text { do Norte }\end{array}$ & 2 & & & & & 2 \\
\hline Pernambuco & 2 & 1 & & & & 3 \\
\hline Sergipe & 1 & & & & & 1 \\
\hline Bahia & 2 & 1 & & & & 3 \\
\hline $\begin{array}{l}\text { Distrito } \\
\text { Federal }\end{array}$ & 1 & & & & & 1 \\
\hline $\begin{array}{c}\text { Mato } \\
\text { Grosso do } \\
\text { Sul }\end{array}$ & 1 & & & & & 1 \\
\hline $\begin{array}{l}\text { Minas } \\
\text { Gerais }\end{array}$ & 1 & & & & & 1 \\
\hline $\begin{array}{l}\text { Espírito } \\
\text { Santo }\end{array}$ & 2 & & & & & 2 \\
\hline $\begin{array}{l}\text { Rio de } \\
\text { Janeiro }\end{array}$ & 5 & 1 & & & & 6 \\
\hline São Paulo & 11 & 3 & & 1 & 1 & 17 \\
\hline Paraná & 2 & & & & & 2 \\
\hline $\begin{array}{c}\text { Santa } \\
\text { Catarina }\end{array}$ & 1 & & 1 & & & 3 \\
\hline $\begin{array}{l}\text { Rio Grande } \\
\text { do Sul }\end{array}$ & 3 & 1 & & & & 4 \\
\hline Total & 40 & 8 & 1 & 1 & 1 & 52 \\
\hline
\end{tabular}

Fonte: Ansarah e Rejowski, 1996: 38 
Tabela 2 - Cursos de Graduação em Turismo, Hotelaria e Áreas afins na Região Nordeste-2003.

\begin{tabular}{|c|c|}
\hline & REGIÃO NORDESTE \\
\hline Estado & Quantidade \\
\hline Alagoas & 5 \\
\hline Bahia & 25 \\
\hline Ceará & 6 \\
\hline Maranhão & 7 \\
\hline Paraíba & 5 \\
\hline Pernambuco & 19 \\
\hline Rio Grande do Norte & 3 \\
\hline Sergipe & 2 \\
\hline Piauí & 4 \\
\hline Total & 76 \\
\hline Fonte: Associação Brasileira de Bacharéis em Turismo - ABBTUR
\end{tabular}

Tabela 3 - Cursos de Graduação em Turismo, Hotelaria e Áreas afins na Região Norte2003.

\begin{tabular}{|c|c|}
\hline & REGIÃO NORTE \\
\hline Estado & Quantidade \\
\hline Amazonas & 6 \\
\hline Acre & 1 \\
\hline Amapá & 2 \\
\hline Pará & 2 \\
\hline Rondônia & 2 \\
\hline Tocantins & 2 \\
\hline Total & 15 \\
\hline
\end{tabular}

Fonte: Associação Brasileira de Bacharéis em Turismo - ABBTUR 
Tabela 4 - Cursos de Graduação em Turismo, Hotelaria e Áreas afins na Região Sul 2003.

\begin{tabular}{|c|c|}
\hline \multicolumn{2}{|c|}{ REGIÃO SUL } \\
\hline Estado & Quantidade \\
\hline Paraná & 40 \\
\hline Santa Catarina & 18 \\
\hline Rio Grande do Sul & 12 \\
\hline Total & 70 \\
\hline \multicolumn{2}{|c|}{ Fonte: Associação Brasileira de Bacharéis em Turismo - ABBTUR } \\
\hline \multicolumn{2}{|c|}{ REGIÃO SUDESTE } \\
\hline Estado & Quantidade \\
\hline Espírito Santo & 10 \\
\hline Minas Gerais & 38 \\
\hline Rio de Janeiro & 26 \\
\hline São Paulo & 149 \\
\hline Total & 223 \\
\hline
\end{tabular}

Fonte: Associação Brasileira de Bacharéis em Turismo - ABBTUR

Tabela 6 - Cursos de Graduação em Turismo, Hotelaria e Áreas afins na Região Centro Oeste- 2003.

\begin{tabular}{|c|c|}
\hline \multicolumn{1}{|c|}{ REGIÃO CENTRO-OESTE } \\
\hline Estado & Quantidade \\
\hline Distrito Federal & 11 \\
\hline Goiás & 12 \\
\hline Mato Grosso & 8 \\
\hline Mato Grosso do Sul & 12 \\
\hline Total & 43 \\
\hline
\end{tabular}

Fonte: Associação Brasileira de Bacharéis em Turismo - ABBTUR 
Outra mudança ocorrida foi quanto à diversificação das áreas de atuação que o profissional pode escolher. Por exemplo, hoje, as Instituições de Ensino Superior (IES) oferecem cursos de turismo com diversas ênfases: graduação em turismo com ênfase em Ecoturismo, em marketing, em ambientes naturais, dentre outros.

Outra observação é que em 1996 só 17 estados possuíam IES que ofereciam cursos de graduação em turismo. Hoje, segundo dados da Associação Brasileira de Bacharéis em Turismo, ABBTUR, somente o estado de Roraima não possui IES que ofereçam formação superior em turismo e o Sudeste ainda é a região que concentra a maioria dos cursos em turismo conforme Figuras 4 e 5.

Figura 4 - Cursos de Turismo e áreas afins por região em quantidade de cursos ano de 2003.

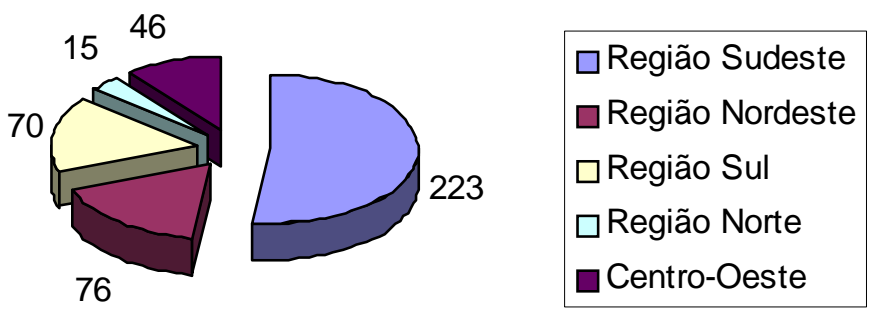

Figura 5 - Cursos de Turismo e áreas afins por região em porcentagem no ano de 2003.

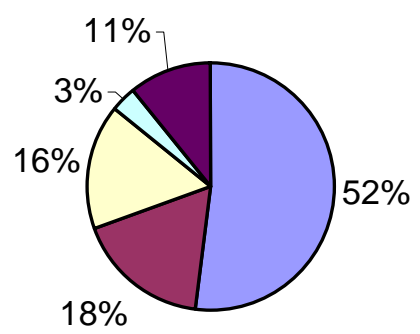


A pergunta que se faz é: esse grande aumento do número de cursos superiores de turismo com a baixa qualidade do ensino não prejudicam a imagem da profissão e do profissional de turismo?

Acredita-se que nem todas as IES que possuem curso superior em turismo e áreas afins oferecem aos alunos um ensino de qualidade. Kostman (2004: 61) informa que "entre novembro de 2001 e julho de 2003, 544 novos estabelecimentos de ensino superior forma autorizados a funcionar pelo Ministério da Educação. Dá quase um por dia". Diante dessa afirmação, acredita-se que nem todas elas possuam estrutura física adequada e ensino de qualidade. Ainda consoante com Kostman, "muitos empresários de diversas áreas investiram como nunca na criação de faculdades". E a qualidade do ensino destas novas faculdades? Também cresceu na mesma proporção? Por isso, defende-se que com uma educação desejável, acredita-se que esses futuros bacharéis em turismo ou turismólogos chegarão ao mercado de trabalho, que está cada vez mais exigente, deixando muito a desejar. Com a evolução do turismo, não cabe lugar para o amadorismo. É necessária uma formação de qualidade para que haja profissionais de qualidade.

Para que isso aconteça, é necessário que ocorram mudanças tanto por parte das IES quanto por parte dos alunos e do corpo docente. Em outras palavras, cabe a cada um fazer o seu papel. São quase 90.000 alunos estudando turismo ${ }^{4}$ e cerca 430 IES que oferecem graduação em turismo e áreas afins.

Por um lado, as IES devem preocupar-se mais com a qualidade dos cursos oferecidos. Elas devem ser faculdades e não fábrica de diplomas, como afirma o Advogado Paulo Guimarães, secretário-geral da Ordem dos Advogados do Brasil $(\mathrm{OAB})$ - Distrito Federal em referência à pulverização das faculdades de direito no Brasil e, por conseqüência, diminuiu a qualidade dos cursos de advocacia. Essa dica vale também para os cursos de turismo que padecem do mesmo problema. Ainda consoante com Paulo Guimarães, lamentavelmente, a origem de todo o

\footnotetext{
${ }^{4}$ Dado citado por Sérgio Brito, consultor da ABBTUR, em palestra feita no dia 24/09/2003 na abertura da solenidade em comemoração ao Dia do Bacharel em Turismo ocorrida no Auditório Ulysses Guimarães da Universidade Unip em Brasília.
} 
problema está no Poder Público. No entanto, não se pretende entrar no assunto, pelo menos neste trabalho.

Como afirma o ex-ministro Paulo Renato de Souza (citado em Kostman, 2004: 62), “... as instituições terão de se preocupar com a qualidade e preço... A concorrência está muito grande". Kostman afirma "deverão ser valorizadas instituições que tiverem mais professores qualificados, bibliotecas e laboratórios bem equipados e, principalmente, que preparem o aluno para o mercado de trabalho".

Outro grande problema identificado diz respeito ao acesso dos alunos na IES. Sabe-se que em muitas Instituições o acesso dá-se por meio do vestibular. Entretanto, percebe-se que o mesmo não é mais levado a sério. Nas palavras de Ryon Braga, presidente da consultoria educacional Hoper, (citado em Kostman, 2004: 62) "o vestibular na maioria das faculdades particulares acabou, é só fachada".

Como afirma Tineu (2002): "as IES devem se preocupar mais com o processo seletivo dos cursos, já que existem deficiências básicas de formação dos alunos, geradas no ensino fundamental e médio".

Algumas IES estão oferecendo, pelo menos no Distrito Federal, um "vestibular agendado" como forma de ingresso na faculdade. É o candidato quem marca a data e hora da prova. São as faculdades "em caça aos alunos".

Depois de passarem pelo vestibular, agendado ou não, verifica-se que muitos alunos não estão preparados para o desafio que é (ou deveria ser) um curso de nível superior.

Pela observação participante in locus como docente em faculdades, observa-se que a maioria dos alunos não possui maturidade nem capacidade intelectual para enfrentar uma faculdade ou universidade. Muitos não conhecem e não usam o dialeto lingüístico padrão. Escrevem errado mesmo! Trocam aceitar 
por "asseitar". Possibilidade por "pocilibilidade". Barzinho por "barsinho". Ônibus por "hônibus".

Além da questão ortográfica, não se mostram interessados pelo conteúdo e pelo aprendizado. $\mathrm{O}$ aluno finge que aprende e o professor finge que ensina. É o jogo do faz de conta.

Acredita-se que muitas IES compactuam com professores e alunos e todos brincam com o jogo do faz de conta.

O depoimento de uma professora mestra de nível superior vem a confirmar o que foi dito anteriormente. Disse ela, que foi orientada pelo diretor da IES a não cobrar muito dos alunos. Os trabalhos deveriam ser feitos dentro de sala de aula não podendo passar tarefas para serem feitas extraclasse. Isso por que muitos alunos trabalham o dia todo e freqüentam a faculdade no horário noturno. O receio do diretor era que se os alunos achassem difícil a matéria apresentada em aula eles poderiam pedir transferência para uma outra IES.

Percebe-se, atualmente, um mercantilismo educacional ou um mercado educacional. O aluno paga e recebe um diploma superior ao final do curso.

Não se pretende julgar quem está certo quem está errado, pois, acredita que o problema é compartilhado pelas IES, pelos alunos e pelo corpo docente. $\mathrm{O}$ que não pode acontecer é que esse jogo do faz de conta continue a estar presente nas IES.

Nas palavras de Boiteux e Werner (2003: 1),

"O Brasil está mudando e a universidade também. Ela hoje tem uma função social, ás vezes ignoradas, que é de proporcionar ensino de qualidade a todas as camadas da população. Encontramos cada vez mais nos bancos escolares a primeira geração que freqüenta uma faculdade. Temos, por conseguinte, 
que nos adaptar rapidamente a tal realidade tanto na preparação do corpo docente como na adequação das ementas e programas".

Por outro lado, cabe ao alunado fazer a sua parte, para não, somente, possuir um diploma de curso superior. Deve se interessar em aprender, questionar, possuir raciocínio crítico e lógico, dentre outras características.

Nas palavras de Demo (2000: 19): "dentro do perfil do trabalhador moderno, entendido como portador central do processo inovativo, trata-se de aprender a aprender, saber pensar... além da formação permanente".

Ainda segundo Demo (2000: 32):

"A sociedade moderna exige um cidadão capaz de estar à sua frente, comandando o processo exponencial de inovação, não correndo atrás, como se fora sucata. Enfrentar desafios novos, avaliar os contextos sócio-históricos, filtrar informação, manter-se permanentemente em processo de formação são responsabilidades inalienáveis...".

No que tange aos docentes, nas palavras de Demo (2000: 55), é necessário que o papel do professor seja redefinido. O autor faz algumas considerações, denominadas Competências Formais do Professor, para que isso ocorra, conforme Tabela 7.

Tabela 7 - Competências Formais do Professor segundo Demo (2000; 55).

\begin{tabular}{|c|}
\hline Competências Formais do Professor \\
\hline Pesquisa \\
\hline Elaboração própria \\
\hline Teorização da prática \\
\hline Formação permanente \\
\hline Manejo dos meios eletrônicos \\
\hline
\end{tabular}


Entende-se que os docentes têm papel fundamental no processo de educação tanto do nível fundamental, médio e superior. No caso de profissionais do turismo, acredita-se que os mesmos devem possuir um perfil com certas particularidades.

Segundo Bolívar (citado em Ansarah 1995: 44), as principais características do profissional de turismo são:

- Aprender a aprender e ter uma ampla formação cultural;

- Ser criativo e inovador, pois enfrentará uma acirrada concorrência no mercado;

- Ser um profissional com suficiente conhecimento teórico-prático para satisfazer as necessidades da demanda.

Acredita-se, então, que ocorrendo tais mudanças sugeridas acima, a grande probabilidade de que o turismo possa ser mais reconhecido no mercado e que e o profissional da área ocupe o lugar que é seu. 


\section{DESCRIÇÃO DA METODOLOGIA DA PESQUISA}

Neste capítulo, abordar-se-á a metodologia utilizada para a realização desta pesquisa.

\subsection{Ciência e Metodologia Científica}

Por ciência entende-se uma forma especial de conhecimento da realidade, É um conhecimento racional, metódico e racional, capaz de ser submetido à verificação (Dencker, 2001: 18).

Já metodologia é entendida como sendo a maneira concreta de se realizar a busca do conhecimento. É o que se faz para adquiri-lo de maneira racional e eficiente (Dencker, 2001: 18).

A diferença entre o conhecimento científico e as demais formas de conhecimento é a maneira como se procede para a sua obtenção. Na busca deste conhecimento científico são utilizados diversos métodos, processos e técnicas.

Nogueira (citado em Dencker, 2001: 19) defende que Método Científico "é a sucessão de passos pelos quais de descobrem novas relações entre fenômenos...". Assim, define-se método como sendo a forma ordenada de proceder a um caminho. Como defini Dencker (2001: 19), método "é o conjunto de processos ou fases empregadas na investigação, na busca do conhecimento. Tal processo pode ser intelectual e operacional".

Dessa maneira, o método dá a orientação geral para se chegar a um fim e a forma de aplicação do método é a técnica. O método estabelece o que fazer; $A$ técnica o como fazer (Dencker, 2001: 20). 


\subsection{Início e Evolução da Pesquisa Turística}

Rejowski (2001: 13) afirma que "o turismo, como qualquer outra área do conhecimento, tem seu desenvolvimento ligado à pesquisa e ao ensino". No que se refere à pesquisa, sabe-se que o início pesquisa turística ocorreu na década de 1870, quanto surgiram os primeiros trabalhos que tratavam do assunto.

Outra característica da pesquisa no turismo foi o fato de ela ter seu desenvolvimento dentro de outras áreas de estudo, como por exemplo, geografia e economia. Ou seja, o turismo torna-se área de estudo a partir de outras disciplinas. Tanto que os primeiros conceitos e definições de turismo foram elaborados com o enfoque da geografia e economia (Rejowski, 2001: 15).

Ainda segundo Rejowski (2001: 38), para compreender o atual estágio da pesquisa e ensino no turismo, é necessário que quatro tópicos sejam abordados: natureza disciplinar, plataforma de estudo, natureza temática e aspectos metodológicos.

A natureza disciplinar do turismo defende que a pesquisa no turismo deuse por meio de outras áreas de estudo, como já citado anteriormente. Quanto à plataforma de estudo, também chamada de abordagens de estudos, tem-se o modelo proposto por Jafari (citado em Rejowski, 2001: 40), que defende que o turismo como área de estudo passou pelas seguintes plataformas:

a) Plataforma de defesa: esta plataforma aborda os aspectos positivos do turismo, tanto economicamente quanto socialmente. Teve seu desenvolvimento no período pós Segunda Guerra Mundial, onde muitos países utilizaram o turismo como forma de reconstrução de suas economias;

b) Plataforma de advertência: ao contrário da plataforma de defesa, aborda as questões negativas da atividade (o turismo prejudica o meio ambiente). Surge na década de 60.

c) Plataforma de adaptação: aborda os aspectos negativos e positivos do turismo e sugere formas alternativas de se praticar a atividade. 
d) Plataforma de conhecimento básico ou científico: pode-se dizer que esta plataforma é a união das plataformas anteriores, pois, aborda o turismo como um todo com seus aspectos positivos e negativos e sugere uma coexistência entre eles.

Já a natureza temática da atividade diz respeito aos temas enfocados sobre o turismo. Por exemplo, nos anos 50 abordaram-se os seguintes temas: ensino em turismo, planejamento territorial e expansão regional. Nos anos 60: medição de fluxos turísticos e administração de empresas turísticas, dentre outros.

Por último, os aspectos metodológicos dizem respeito ao desenvolvimento de metodologias e técnicas de medida utilizadas na pesquisa em turismo. Mesmo sendo o turismo uma atividade recente quanto a este aspecto, algumas metodologias de pesquisa já existem.

Um destes aspectos metodológicos foi proposto por Kunhe (citado em Rejowski, 2001: 44) e diz respeito à forma de abordá-los. Para ele, estudos em turismo podem ser vistos de maneira reducionista (visão reducionista), holística (visão holística) e sistêmica (visão sistêmica).

a) Visão Reducionista: analisa minuciosamente o todo dentro do qual estão inseridos objetos particulares. O foco de estudo é sobre os elementos, não sobre as inter-relações;

b) Visão Holística: o holismo considera todas as partes como inseparáveis e, por tanto, não-analisáveis isoladamente;

c) Visão sistêmica: segundo esta visão, a análise do turismo como sistema permite observar particularidades do todo e, ao mesmo tempo, propriedades específicas das partes que compõem esse todo.

Dann, Nash e Pearce (citado em Rejowski, 2001: 46) também sugeriram alguns procedimentos metodológicos a partir da análise de artigos. Para eles, a metodologia de pesquisa em turismo pode ser: 
a) Descritiva: análises que não testam uma hipótese ou que buscam empiricamente validar o propósito de pesquisa;

b) Apoiadas em Base Conceitual: análises que são baseadas em trabalhos anteriores, isto é, ligados por argumentos e lógica de estudos prévios;

c) Modelos: análises que contêm referência a ou são extensão de um modelo para sistematização de comportamentos;

d) Estatísticos: análises que utilizam técnicas de estatística descritiva e inferência de alto nível.

Já McIntosch e Goeldner (citado em Rejowski, 2001: 48) apresentam três métodos básicos de pesquisa em turismo:

a) Survey: é conhecido como técnica de questionário. Pode ser conduzido por entrevistas pessoais, pelo correio, por telefone ou, ainda, por máquinas;

b) Observação: consiste na observação direta do fenômeno físico para a coleta dos dados. Mais objetivo e acurado do que o survey. Os dados podem ser coletados mecanicamente ou pessoalmente;

c) Experimentação: envolve a construção e aplicação de um teste, modelo ou experimentação, para simular o mundo real. Medem-se as variações de uma ou mais atividades, enquanto todas as outras condições são controladas. É difícil seu uso no turismo em face das dificuldades de manter as variáveis constantes.

\subsection{A Pesquisa}

Pode-se afirmar que pesquisa é toda atividade voltada a solução de problemas. É a busca, indagação e investigação da realidade. No ambiente da ciência, a pesquisa permite a elaboração do conhecimento ou de conjuntos de conhecimentos que ajudem na compreensão da realidade (Dencker, 2001: 48). 
As etapas da pesquisa em turismo são projeto de pesquisa, coletas de dados, análise dos dados e elaboração escrita e são interdependentes.

O projeto de pesquisa pode ser definido como o documento que explicita as ações que serão desenvolvidas ao longo do processo de pesquisa. É útil, pois orienta o pesquisador sobre o que deve ser feito.

A coleta de dados é a fase da pesquisa que tem por objetivo obter informações sobre a realidade. Os tipos mais comuns de coletas de dado são a entrevista e o questionário, embora existam, atualmente, outros tipos. Por exemplo, Internet, fax, tv interativa.

Por entrevista entende-se como sendo o "a comunicação verbal entre duas ou mais pessoas, com grau de estruturação previamente definido, cuja finalidade é a obtenção de informações de pesquisa" (Dencker, 2001: 137).

O questionário é a maneira sistemática e ordenada de se obter informações sobre as variáveis que intervêm na investigação.

Depois da coleta de dados, procedem-se a análise e interpretação dos dados. A análise tem por objetivo reunir as informações de maneira coerente e organizada. Já a interpretação busca dar um sentido aos dados coletados.

A elaboração escrita da pesquisa é a fase onde são reunidos todos os resultados da pesquisa e escritos em um documento. Como exemplo, tem-se a monografia que, nas palavras de Dencker (2001: 239), "é o estudo por escrito de um único tema específico, bem delimitado".

\subsection{Trajetória da Pesquisa}

Para a realização desta pesquisa, foi elaborado, em primeiro lugar, um projeto de pesquisa (maio de 2003). Nele foram definidos o problema da pesquisa, os objetivos e hipóteses do trabalho. Foram apresentadas, também, a justificativa do tema, a revisão bibliográfica e a metodologia de pesquisa. 
A próxima fase foi a coleta de dados. O tipo de coleta escolhido foi 0 questionário. De acordo com Vellasco (2002: 23), em uma pesquisa,

“o questionário é um instrumento ou programa de coleta de dados. É elaborado pelo pesquisador e preenchido pelo informante. A linguagem utilizada no questionário deve ser simples e direta para que o informante compreenda com clareza o que está sendo perguntado. Não é recomendado o uso de gírias, a não ser que se faça necessário por necessidade de características de linguagem do grupo (grupo de surfistas, por exemplo). Todo questionário a ser enviado deve passar por uma etapa de pré-teste, em um universo reduzido, para que se possam corrigir eventuais erros de formulação".

Os questionários, constantes do Apêndice, foram elaborados no mês de setembro de 2003 e aplicados nos meses de setembro e outubro. Foram elaborados dois tipos de questionários: questionário $A$ e questionário $B$. O primeiro com a intenção de ser aplicado junto às pessoas que não tinham relação ou não trabalham na atividade turística. E o segundo para ser aplicado junto às pessoas que tinham alguma relação com a área, por exemplo, estudantes do curso de turismo.

Os questionários de tipo A foram aplicados na Rodoferroviária e Aeroporto. Já os questionários de tipo B foram aplicados aos alunos do curso de turismo nas seguintes Instituições de Ensino Superior: Universidade Paulista - UNIP, Faculdade Cenecista de Brasília - FACEB e União Pioneira de Integração Social - UPIS.

Ambos possuem perguntas abertas e fechadas. O questionário tipo $A$ possui três questões enquanto o tipo B possui seis. 
Aplicaram-se 60 do tipo A e 145 questionários do tipo B. O número de questionário tipo A foi menor, pois nem todas as pessoas quiseram respondê-lo. Fenômeno não ocorrido quanto ao tipo B, pois, eles foram aplicados nas IES. Os alunos responderam prontamente.

Depois de aplicados os questionários, analisaram-se e interpretaram-se os resultados da pesquisa (novembro de 2003).

Para a classificação, obedeceram-se os critérios sugeridos por Dencker (2001: 159):

- Não ter mais de um critério na mesma classificação;

- A classificação deve abranger todas as categorias possíveis;

- As classificações devem se excluir mutuamente.

Como foram elaborados dois tipos de questionários, a análise dos dados se construiu separadamente, mas de forma integrada cujos resultados estão no capítulo 4. 


\section{ANÁLISE DOS DADOS}

Depois de especificada a trajetória desta pesquisa e analisado seus dados, obtiveram-se os dados a seguir.

No que tange ao questionário tipo $\mathrm{A}$, o total de pessoas que respondeu ao questionário foi 60. Da 60 pessoas, 27 eram do sexo feminino e 33 do sexo masculino (Verificar Figura 6).

Figura 6 - Distribuição por Sexo. Questão 1/Tipo A

\section{Distribuição por sexo}

$\square$ Feminino

$\square$ Masculino

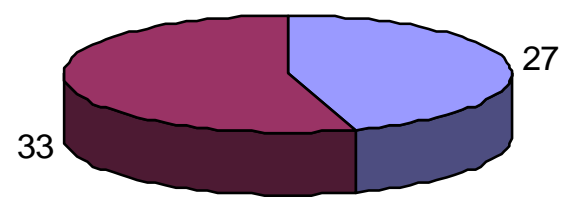

A segunda questão do questionário tipo A foi elaborada com a intenção de analisar o que as pessoas, que supostamente não trabalham na área, pensam o que seja turismo. (Na sua opinião, o que é turismo?).

Das 60 pessoas, 27 acham que "turismo é viajar e conhecer novos lugares, novas culturas e novos costumes", de acordo com a tabela 8. Dez pessoas afirmaram que "turismo é uma forma de ocupar o tempo livre e uma forma de lazer".

Cinco pesquisados responderam que turismo "é o movimento de pessoas fora do seu local de residência por diversos motivos ou são pessoas que se deslocam para fugir do cotidiano". 
Tabela 8 - O que é Turismo? - Questão 2/Tipo A

\begin{tabular}{|c|c|c|}
\hline O que é Turismo? & Freqüência & $\%$ \\
\hline $\begin{array}{c}\text { "Turismo é viajar e conhecer novos } \\
\text { lugares, novas culturas e novos } \\
\text { costumes". }\end{array}$ & 27 & 45 \\
\hline $\begin{array}{l}\text { "Turismo é uma forma de ocupar o } \\
\text { tempo livre e uma forma de lazer". }\end{array}$ & 10 & 16,8 \\
\hline $\begin{array}{l}\text { "Movimento e deslocamento de } \\
\text { pessoas". }\end{array}$ & 5 & 8,4 \\
\hline "Área de estudo. É uma ciência". & 5 & 8,4 \\
\hline $\begin{array}{c}\text { Ramo da economia que comercializa } \\
\text { lazer e entretenimento. }\end{array}$ & 1 & 1,6 \\
\hline $\begin{array}{l}\text { Fenômeno social e econômico } \\
\text { que perpassa diversos campos e } \\
\text { segmentos da sociedade, } \\
\text { produzindo relações e gerando } \\
\text { resultados das mais variadas } \\
\text { naturezas. }\end{array}$ & 1 & 1,6 \\
\hline Forma de divulgação do País & 1 & 1,6 \\
\hline $\begin{array}{l}\text { Junção de recreação e } \\
\text { conhecimento. }\end{array}$ & 1 & 1,6 \\
\hline Outros & 9 & 15 \\
\hline Total & 60 & 100 \\
\hline
\end{tabular}

Somente cinco pessoas consideram "turismo como uma área de estudo e ciência que engloba outras várias ciências (interdisciplinaridade)". Além disso, disseram que "é uma área que explora diversas manifestações de uma região para tentar atrair visitantes". 
Uma pessoa afirmou que "turismo é um ramo da economia que comercializa lazer e entretenimento", enquanto outra acredita que "turismo é um fenômeno social e econômico que perpassa diversos campos e segmentos da sociedade, produzindo relações e gerando resultados das mais variadas naturezas".

"Turismo é uma forma de apresentar e divulgar um país" é a opinião de mais um pesquisado.

"Turismo é a junção de recreação e conhecimento" foi o que responderam 03 pessoas.

A terceira pergunta foi: Na sua opinião, o que faz o profissional de turismo? Qual sua visão sobre ele?

Dos 60 questionários respondidos, 40 pessoas disseram que o profissional de turismo "é aquele que organiza e orienta viagens e elabora roteiros turísticos. São profissionais que informam sobre os aspectos culturais e históricos de uma cidade". Por outro lado, elas acham que "tais profissionais são importantes para a atividade, pois, são responsáveis pelo desenvolvimento da atividade e por conscientizar os outros sobre a importância do turismo. Além disso, elas acreditam que mesmo assim, esses profissionais não são reconhecidos no mercado de trabalho" (Verificar Tabela 9).

Sete pessoas acreditam que o profissional de turismo é aquele que sabe de tudo um pouco. É eclético e pode trabalhar como guia, com hospedagem, alimentação ou eventos.

Outras duas pessoas disseram que o profissional de turismo é o responsável pelo desenvolvimento de um destino turístico. 
Tabela 9 - O que faz o profissional de turismo? - Questão 3/Tipo A

\begin{tabular}{|c|c|c|}
\hline $\begin{array}{c}\text { Na sua opinião, o que faz o } \\
\text { profissional de turismo? Qual sua } \\
\text { visão sobre ele? }\end{array}$ & Freqüência & $\%$ \\
\hline $\begin{array}{c}\text { Organiza e orienta viagens. } \\
\text { É eclético. Deve saber de tudo um } \\
\text { pouco. }\end{array}$ & 40 & 66,7 \\
\hline $\begin{array}{c}\text { É o responsável pelo } \\
\text { desenvolvimento de um destino } \\
\text { turístico. }\end{array}$ & 2 & 11,7 \\
\hline Não tem opinião. & & 3,3 \\
\hline Outros & 2 & 3,3 \\
\hline Total & 9 & 15 \\
\hline
\end{tabular}

Somente dois participantes disseram que não tem nenhuma opinião sobre o que faz o profissional da área.

Quanto ao questionário de tipo B, obtiveram-se os seguintes resultados: dos 145 alunos que responderam às questões, 87 eram do sexo feminino e 58 do sexo masculino (Figura 7).

Figura 7 - Distribuição por Sexo. Questão 1/Tipo B

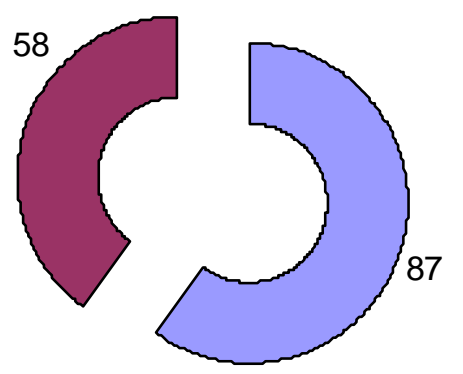


O corpo discente pesquisado é composto, em sua maioria, por jovens de faixa etária entre 20 a 29 anos (Figura 8).

Figura 8 - Distribuição por Faixa Etária. Questão 2/Tipo B

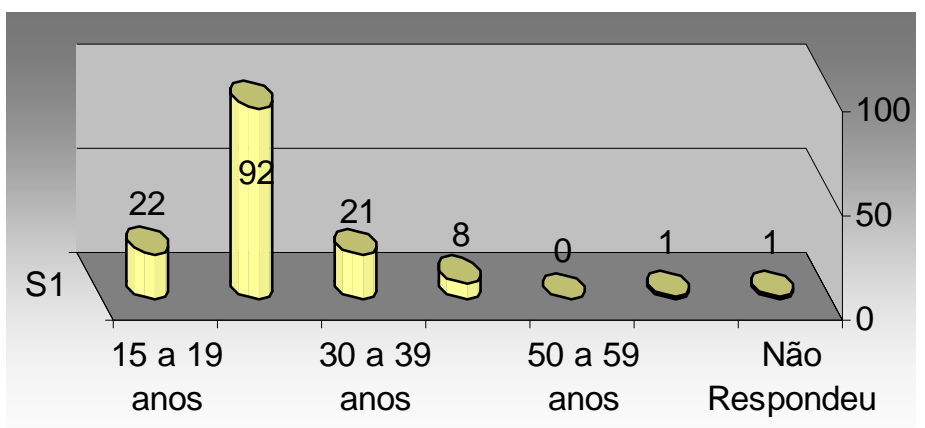

Quanto ao grau de escolaridade dos estudantes, 139 estão fazendo o primeiro curso de nível superior, um já possui pós-graduação, quatro fazem o segundo curso e 1 não respondeu. (Figura 9).

Figura 9 - Distribuição por Sexo. Questão 3/Tipo B
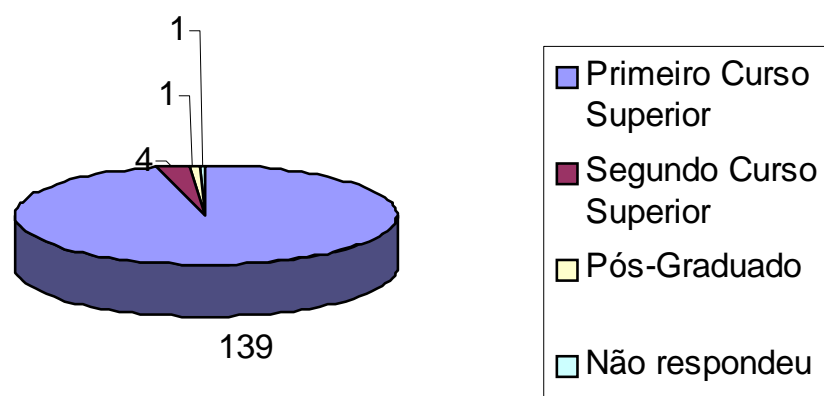

A questão de número 4 pretendia analisar o motivo pelo qual o aluno decidiu estudar turismo (Porque você resolveu estudar na área de Turismo?). Como a pergunta era aberta, os resultados variaram muito (Verificar Tabela 10). 
Tabela 10 - Motivos para Estudar Turismo - Questão 4/Tipo B

\begin{tabular}{|c|c|c|}
\hline Motivos para estudar Turismo & Freqüência & $\%$ \\
\hline "É a profissão do futuro" & 67 & 46,20 \\
\hline $\begin{array}{c}\text { Conhecem pessoas que trabalham } \\
\text { na área }\end{array}$ & 11 & 7,59 \\
\hline "Identifico-me com a área" & 9 & 6,20 \\
\hline $\begin{array}{c}\text { "Gosto de viajar e conhecer novas } \\
\text { culturas" }\end{array}$ & 10 & 6,20 \\
\hline Falta de Opção & 6 & 4,14 \\
\hline $\begin{array}{l}\text { Por gostar da natureza e meio } \\
\text { ambiente }\end{array}$ & 5 & 2,75 \\
\hline Por ser uma área abrangente & 6 & 2,75 \\
\hline "Brasil é um país turístico" & 4 & 1,39 \\
\hline "Gosto de trabalhar com o público" & 4 & 2,75 \\
\hline Por adorar geografia & 2 & 1,39 \\
\hline Para continuar estudando & 4 & 2,75 \\
\hline Valor da mensalidade & 2 & 1,39 \\
\hline Por curiosidade & 2 & 1,39 \\
\hline $\begin{array}{c}\text { Para possuir um diploma de curso } \\
\text { superior }\end{array}$ & 1 & 0,69 \\
\hline Por estudar inglês & 1 & 0,69 \\
\hline Outros & 11 & 7,59 \\
\hline Total & 145 & 100 \\
\hline
\end{tabular}

Dos 145 pesquisados, 67 decidiram estudar turismo por acreditarem que essa é uma área em crescimento e por considerarem que turismo é a profissão do futuro ("É a profissão do futuro", "É uma área promissora", Turismo cresce a cada dia"). 
Onze alunos responderam que "decidiram estudar turismo por já trabalharem na área ou porque já conhecem pessoas atuam na atividade turística".

Dez alunos responderam que adoram viajar, conhecer novos lugares e culturas e, por isso, decidiram estudar turismo ("Gosto de viajar", "Quero conhecer novos lugares e culturas").

Seis alunos disseram que resolveram estudar turismo por falta de opção ou por acaso ("Única opção que tinha", Falta de opção ")".

Gostar da natureza e do meio ambiente (Ecoturismo) foram outros motivos respondidos por cinco alunos.

Seis alunos optaram estudar turismo por ela ser uma área abrangente. Outros quatros afirmaram que o Brasil é um país turístico. Para tal, necessita de profissionais qualificados e que o turismo crescerá com o governo do Presidente Lula. Um desses, respondeu que ama o Brasil. Eis o motivo que o levou a entrar na área.

Gostar de trabalhar com o público foi a razão que levou quatro alunos a estudarem turismo. Dois disseram que "adoram trabalhar com geografia e acham que o turismo tem tudo a ver com essa disciplina".

A necessidade de continuar estudando e para ampliar a área de atuação foi o motivo que levou mais quatro alunos a optarem pela área.

O valor da mensalidade também foi fator que influenciou dois estudantes a estudarem turismo e a curiosidade pelo curso foi motivo para dois alunos.

A questão cinco quis saber qual era a visão que o aluno tinha do turismo antes e depois de entrar no curso superior (Qual a sua visão sobre turismo antes e após estudar ou trabalhar na área?). 
A maioria dos estudantes (52 dos pesquisados) achava que estudar turismo era só viajar ("Turismo, para mim, era só curtição"). Por outro lado, esses mesmo alunos que pensavam dessa assim, depois, de conhecerem um pouco mais sobre a área, já pensam diferente. Agora, acreditam que turismo é uma área importante e que são necessários profissionais qualificados para atuarem na área (Verificar Tabela 11).

Outros trintas alunos imaginavam que o curso de turismo era ruim e que não tinham utilidade nenhuma para o profissional da área. Hoje, porém, acreditam que o curso é essencial para um profissional que pretende atuar na área. Acreditam, também, que a atividade turística, quando bem desenvolvida, pode colaborar para o desenvolvimento do Brasil.

Onze alunos responderam que depois de conhecer um pouco mais sobre o assunto é que verificaram que o turismo no Brasil ainda tem muito para se tornar melhor.

Sete alunos disseram que continuam com a mesmo visão.

Mais três estudantes afirmaram que estudar turismo é melhor do que parece. Cinco alunos achavam que qualquer pessoa estria apta a trabalhar com turismo. Depois de conhecer um pouco mais sobre a atividade, acham importante o papel do turismólogo.

Uma aluna considerava que o turismo só poderia ser praticado por pessoas ricas. Agora pensa de maneira diferente. Três alunos pensavam que turismo era uma área promissora. Agora têm certeza. 
Tabela 11 - Visão sobre Turismo Antes e Depois de Entrar na Faculdade - Questão 5/Tipo B

\section{Visão sobre Turismo Antes e Depois de entrar na Faculdade}

"Turismo era só viajar. Agora vejo que é diferente".

"Depois de entrar na faculdade, vejo que o turismo ainda tem muito para ser melhorado".

\begin{tabular}{|c|c|c|}
\hline $\begin{array}{l}\text { "Continuo com a mesma visão de } \\
\text { antes". }\end{array}$ & 7 & 4,83 \\
\hline $\begin{array}{c}\text { "Estudar turismo é melhor do eu } \\
\text { esperava". }\end{array}$ & 3 & 2,06 \\
\hline $\begin{array}{c}\text { "Pensava que qualquer pessoa } \\
\text { podia trabalhar com turismo. Agora } \\
\text { vejo que é necessário um } \\
\text { profissional" "Agora vejo como é } \\
\text { essencial o trabalho do turismólogo } \\
\text { para a atividade turística". }\end{array}$ & 5 & 3,44 \\
\hline $\begin{array}{c}\text { "Achava que fazer turismo era só } \\
\text { para pessoas ricas. Agora penso } \\
\text { diferente. Os pobres também podem } \\
\text { fazer turismo". }\end{array}$ & 1 & 0,69 \\
\hline $\begin{array}{l}\text { "Pensava que turismo era uma área } \\
\text { promissora. Agora tenho certeza". }\end{array}$ & 3 & 2,06 \\
\hline Outros & 33 & 22,76 \\
\hline Total & 145 & \\
\hline
\end{tabular}


Quanto à última questão, número 6, tentou-se saber qual era a visão que os pesquisados tinham do profissional da área (Qual sua visão sobre o profissional de Turismo?).

Quarenta e seis responderam que as qualidades que o profissional de turismo deve ter são, por exemplo, deve ser um bom comunicador, deve conhecer diversas culturas. No entanto, trinta e oito têm uma visão ruim do profissional, pois, acham que eles não estão comprometidos com a área, acham que são profissionais desqualificados, conforme mostra a Tabela 11.

Por outro lado, dez consideram que os profissionais da área terão um futuro brilhante e serão reconhecidos no mercado, pois, turismo é a profissão do futuro.

Quinze afirmam que a visão que tem do profissional da área é muito boa e são os profissionais os responsáveis por desenvolver um turismo de qualidade.

Somente três acham que o profissional da área viaja bastante. 


\section{CONSIDERAÇÕES FINAIS}

Como resultado final deste trabalho faz-se algumas considerações, a seguir.

É visível o aumento ocorrido nos cursos superiores de turismo, como também, na diversificação das áreas de atuação, por exemplo, Graduação em Turismo com Ênfase em Eventos, Graduação em Turismo e Lazer, entre outros. Em 1996, segundo dados da professora Marília Ansarah, havia cerca de 52 cursos superiores em turismo. Já dados de 2003 mostram que este número é de, aproximadamente, 52;

Acredita-se que esse crescimento tem aspectos negativos e positivos. Como aspecto positivo, pode-se citar a importância que o turismo vem conquistando nos últimos tempos. Caso contrário não haveria tantas pessoas interessadas em estudá-lo. Como aspecto negativo, cita-se o que se pode chamar de mercantilização da educação. A educação virou, em muitos casos, mercadologia, troca. O aluno paga e recebe um diploma ao final do curso. Sabese que muitas faculdades ou universidades não têm estrutura física e nem interesse real de uma educação de qualidade que prepare profissional para o mercado de trabalho. Como proposta para estes aspectos negativos, Sugere-se que as IES, o corpo discente e o corpo docente analisem seu papel na educação em turismo, conforme proposto no capítulo 2.

No que diz respeito opinião que muitos tem sobre o turismo e o profissional da área cujo assunto é um dos objetivos deste trabalho, percebe-se que no geral, a opinião que muitas pessoas têm sobre o turismo ainda é ruim e, em alguns casos, pejorativa. Pôde-se verificar isto nos resultados da pesquisa e apresentados no capítulo anterior. Acredita-se que isso ocorre pela falta de conhecimento que muitos têm sobre a atividade. É o que mostra a tabela 11. Antes de entrarem da faculdade, muitos alunos desconheciam o que é realmente turismo e, conseqüentemente, achavam que turismo era só viajar. Agora que estão na faculdade e por conhecerem o assunto melhor, já pensam de maneira 
diferente. Sabe-se que a viagem é parte do turismo. É a concretização da vontade que muitos tem de fazer turismo. No entanto, turismo é algo mais complexo que uma viagem. Compreender o que é turismo no sentido mais profundo da palavra é compreender e respeitar os povos, seus costumes, sua cultura e história. Como afirma Grinover (2002:28), o "turismo permite a construção social da pessoa, da afirmação da individualidade e da socialização. Fazer turismo consiste em ir e voltar modificado".

Além disso, quando se estuda turismo, aprende-se muito mais do que planejar e organizar viagens. O curso de turismo é abrangente. Estuda-se sobre a legislação turística, sobre planejamento turístico, sobre hotelaria e eventos, dentre outros. Outra observação é que o profissional de turismo não vive viajando como muitos pensam.

Outra consideração a ser feita, diz respeito ao modo como os próprios estudantes de turismo vêm o profissional da área. Ao mesmo tempo em que eles defendem que tal profissional terá um futuro promissor, eles concordam que o profissional que o profissional em questão não é reconhecido no mercado de trabalho, muitas vezes é um profissional desqualificado, conforme mostra a Tabela 9. Por isso, defende-se que com uma educação de qualidade, tais profissionais terão condição de mudar a idéia que muitos têm sobre ele.

Um outro resultado a ser considerado diz respeito ao sexo e faixa etária do corpo discente. Fazendo-se uma comparação entre os dados da pesquisa feita pela professora Marilia em 1995 e a feita agora em 2003, percebe-se que não houve mudanças significativas destes dados. Ainda há predominância do sexo feminino dentre os estudantes de turismo e a faixa etária dos alunos quase não sofreu alteração.

Depois de apresentados e comentados os resultados finais, defende-se a importância que este trabalho tem para o turismo, principalmente no que diz respeito à educação para o turismo, pois, a atividade turística é recente e vem crescendo consideravelmente neste país. Para que tal atividade possa trazer benefícios aos diversos atores do trade turístico - empresários, população local, 
governo - ela tem que ser desenvolvida por profissionais competentes e qualificados para tal.

Acredita-se que este trabalho possa ser importante para quem pesquisa e estuda sobre turismo, pois há uma carência de estudos que tratam sobre o assunto, como também, é um trabalho que engloba um tema atual e importante para o turismo nacional. Por isso, acredita-se que este trabalho possa servir de base para outros e sugere-se que tais pontos devam ser considerados: as políticas educacionais para o turismo, análise da importância do atual presidente para com o turismo, qual a importância do turismo para o atual governo, mudanças ocorridas na educação depois da elaboração deste trabalho, entre ouros. 


\section{APÊNDICES}

\section{Questionário A}

\section{Orientações:}

Este questionário tem como objetivo servir de base e fornecer dados para a pesquisa realizada pela estudante do curso de especialização Pesquisa e Docência em Turismo e Hospitalidade, Leone Carneiro Santos, que trata da imagem e opinião que as pessoas têm sobre o Turismo e os Profissionais da Área.

Conto com sua colaboração para responder as questões abaixo com a maior clareza possível para que se possa obter um melhor conhecimento da realidade.

\begin{tabular}{||l|l|l|}
\hline 1. Sexo & ( ) Masculino & $(\quad$ ) Feminino \\
\hline
\end{tabular}

2. Na sua opinião, o que é Turismo?

3. Na sua opinião, o que faz o profissional de Turismo? Qual a sua visão sobre ele? 


\section{Questionário B}

\section{Orientações:}

Este questionário é parte integrante da pesquisa realizada pela pósgraduanda Leone Carneiro Santos, que trata da imagem e opinião que as pessoas têm sobre o Turismo e os Profissionais da Área.

Este questionário tem como objetivo servir de base e coletar dados de pessoas que estudam ou trabalham na área de Turismo.

Conto com sua colaboração para responder as questões abaixo com a maior clareza possível para que se possa obter um melhor conhecimento da realidade.

1. Sexo

( ) Masculino

( ) Feminino

2. Faixa Etária

$$
\begin{aligned}
& \text { ( ) } 15 \text { a } 19 \text { anos } \\
& \text { ( ) } 30 \text { a } 39 \text { anos } \\
& \text { ( ) } 50 \text { a } 59 \text { anos }
\end{aligned}
$$

( ) 20 a 29 anos

( ) 40 a 49 anos

( ) acima dos 60 anos

3. Grau de Escolaridade

$$
\begin{aligned}
& \text { ( ) } 1^{\circ} \text { Grau completo } \\
& \text { ( ) } 2^{\circ} \text { Grau completo } \\
& \text { ( ) Superior completo } \\
& \text { ( ) Pós-Graduação }
\end{aligned}
$$

$$
\begin{aligned}
& \text { ( ) } 1^{\circ} \text { Grau incompleto } \\
& \text { ( ) } 2^{\circ} \text { Grau incompleto } \\
& \text { ( ) Superior incompleto } \\
& \text { () Outros }
\end{aligned}
$$

4. Porque você resolveu estudar na área de Turismo?

5. Qual a sua visão sobre turismo antes e após estudar ou trabalhar na área?

6. Qual sua visão sobre o profissional de Turismo? 


\section{REFERENCIA BIBLIOGRÁFICA}

ANDRADE, José Vicente de. Turismo Fundamentos e Dimensões. 5. ed. São Paulo: Ática, 1998.

ANSARAH, Marília Gomes dos Reis (org). Turismo: como aprender, como ensinar. 2. ed. São Paulo: Senac, 2001. Volume 2.

Educação e Formação do Bacharel em Turismo. Turismo em Análise, 44 a 64, maio, 1995.

: REJOWSKI, Mirian. Panorama do Ensino no Brasil: Graduação e Pós

- Graduação. Turismo em Análise, 36 a 61, maio, 1996.

BENI, Mário Carlos. Análise estrutural do Turismo. 2. ed. São Paulo: Senac, 1998.

Experiência Internacional do Ensino em Turismo e Hotelaria: Modelos para Avaliação. Turismo em Análise, 7 a 21, novembro, 1992.

BRASIL. Plano Nacional de Turismo 2003 - 2007. Ministério do Turismo. Brasília. 2003.

BRASIL. Lei n. 9.394, de 20 de dezembro de 1996. Estabelece as diretrizes e bases da educação nacional. Câmara dos Deputados. 2. ed. Brasília, 2001.

CORTEZ, Luís. Educação Para um Futuro Sustentável. Jornal da Unicamp. Campinas, 13 a 19 de outubro de 2003, ํ233, pág. 2.

DEMO, Pedro. Educação e Qualidade. 5. ed. Campinas. Papirus, 2000.

DE LUCCA FILHO, Vinícius. Entrei no curso de Turismo. E agora? Estudos Turísticos, jan. 2003. Artigo Disponível na Internet em: http://www.estudosturisticos.com.br, acesso em mar 2003. 
GUIMARÃES, Paulo. Faculdades ou Fábricas de Diplomas. Brasília Em Dia, 4 a 6, setembro, 2003.

GRINOVER, Lúcio. Hospitalidade: Um Tema a Ser Reestudado e Pesquisado. Apostila do Centro de Excelência em Turismo da Universidade de Brasília, setembro, 2003.

KOSTMAN, Ariel. Procuram-se alunos. . Revista Veja, 61 a 62, 21 de janeiro de 2004.

LAGE, Beatriz Helena Gelas; MILONE, Paulo César. Turismo: Teoria e Prática. São Paulo: Atlas, 2000.

OLIVEIRA, Antônio Pereira. Turismo e Desenvolvimento. Planejamento e Organização. 4. ed. São Paulo: Atlas, 2002.

ORGANIZAÇÃO MUNDIAL DO TURISMO. Introdução ao Turismo. São Paulo: Roca, 2001.

Educando os Educadores em Turismo: Manual de Educação em Turismo e Hospitalidade. São Paulo: Roca, 2001.

REJOWSKI, Mirian. Turismo e Pesquisa Científica. 5. ed. São Paulo: Papirus, 2001.

TEIXEIRA, Rivanda. Ensino Superior em Turismo e Hotelaria no Brasil: Um Estudo Exploratório. Estudos Turísticos, out. 2003. Artigo Disponível na Internet em: http://www.estudosturisticos.com.br, acesso em out 2003.

TRIGO, Luiz Gonzaga Godoi Trigo (org). Turismo: como aprender, como ensinar. 2. ed. São Paulo: Senac, 2001. Volume 1 
O Problema da profissionalização em Turismo no Brasil. Entre a Ingenuidade e a Má-Fé. Estudos Turísticos, abr. 2003. Artigo. Disponível na Internet em: http://www.estudosturisticos.com.br, acesso em mar 2003.

TINEU, Rogério. Reflexões sobre a problemática do ensino Superior de Turismo no Brasil. Estudos Turísticos, out. 2002. Artigos. Disponível na Internet em: http://www.estudosturisticos.com.br, acesso em abr 2003.

VELLASCO, Ana M. de M. S. Manual de Orientações para a Produção de Textos Acadêmicos. Universidade de Brasília/Centro de Excelência em Turismo. 2003,197 páginas, formato A-4. 